\title{
LITERAL MEANS AND HIDDEN MEANINGS: A NEW ANALYSIS OF SKILLFUL MEANS
}

\author{
Asaf Federman \\ Department of Psychology, University of Warwick
}

\section{Introduction}

Skillful means is usually used by scholars and Buddhists to denote the following simple idea: the Buddha skillfully adapted his teaching to the level of his audience. ${ }^{1}$ This very broad and somewhat oversimplified definition tries to incorporate the whole range of Buddhist views on the subject. However, it does not help to explain why there is an extensive use of the term in central Mahāyāna sūtras while pre-Mahāyāna texts are almost completely silent on this issue. I suggest that skillful means has not always been an all-Buddhist concept; rather, it was developed by Mahāyānists as a radical hermeneutic device. As such, skillful means is a provocative and sophisticated idea that served the purpose of advancing a new religious ideology in the face of an already established canonical knowledge. The Mahāyāna use of the concept exhibits an awareness, not found in pre-Mahāyāna thought, of a gap between what texts literally say and their hidden meaning.

In 1978 Michael Pye wrote that "'skilful means' has scarcely been attended to at all." 2 Since then, some attention has been given to the ethical, practical, and religious implications of the concept. ${ }^{3}$ Nevertheless, no one has ever asked why an idea that is considered to be so central to Buddhism in general did not become widely recognized before the arising of Mahāyāna. The compound skillful meansupāyakauśalya in Sanskrit or upāya kusala in Pāli-is not entirely a Mahāyāna creation; however, in Mahāyāna sūtras it has become widely used and has been charged with a special and novel meaning. The Mahāyāna interpretation adds a new and crucial layer to the pedagogical meaning of skillful means. It is aimed, eventually, at convincing those at whom it was directed that a new religious path (yāna) was greater than the old one. Critical reading of relevant portions of two early Mahāyāna sutras - the Lotus Sütra and the Skill in Means Sütra-shows how the idea of skillful means is used to achieve this end: it explains how the old doctrine was at the same time not entirely true and not entirely false. This peculiar position is achieved by inventing an interpretive methodology, skillful means, that treats facts as nothing but educational literature. It allows Mahāyānists to challenge central Buddhist paradigms and offer a reorientation of the facts. The idea of skillful means allows a rejection of old literal statements about the life of the Buddha in order to charge them with new meaning. The old ideology is treated as skillful means; that is, it was offered for a specific purpose and is not completely true. On the other hand, as educational fiction, it had its good purpose. 
The idea that the doctrine is some kind of a purposeful fiction is one step further from what is sometimes understood by skillful means: the idea that the dharma is designed to serve a purpose. It is based on the explicit idea that what has been said by the Buddha had a different and concealed meaning. The Pāli canon, for example, contains no such distinction. In the Pâli canon the words and actions of the Buddha are taken literally, and are treated as if the Buddha really meant them. There is no recognition of a gap between words or actions on the one hand and their meaning on the other. There is no recognition, for example, that religious goals were put forward only for the sake of achieving different (or, worse, contradictory) goals. On the other hand, in the early Mahāyāna teaching of skillful means, a gap is recognized between what the Buddha said or did and the meaning of his actions and words. The words of the Buddha then stop being taken literally and begin to be treated as textual entities as if they had been originally put together with concealed intentions. Indeed, Mahāyānists came up with a novel and radical idea: in early Buddhist teaching the literal level was different from the intentional level.

Why did Mahāyānists come up with such a radical idea? Primarily, I speculate, because it solved a well-known religious problem: how to suggest a significant doctrinal change without appearing completely heretical. Being part of an already more or less established tradition, "Mahāyānists" (probably not referring to themselves as such) had to consider carefully the relationship with what has already been established as the ruling paradigm. Whether this position was adopted for political reasons or because of real sentiment for the old, they could not criticize the existing body of religious facts by completely ignoring or rejecting it. The idea of skillful means is therefore an ingenious exercise in religious reformation through reinterpretation. In this sense, it is a hermeneutical device.

\section{Two Kinds of Skillful Means}

Some scholars, probably influenced by the first edition of Pye's monograph (1978), assert that the idea of skillful means is present even in the pre-Mahāyāna forms of Buddhism. ${ }^{4}$ It is generally accepted that the Buddha skillfully applied various means to deliver his understanding of truth and to help other beings to progress on the path to awakening. It is true that this pedagogical aspect of the Buddha's activity is indeed part of Buddhism, but strictly speaking it should not be referred to as skillful means (in short: upāya). Skillful means is a special technical term that was introduced in early Mahāyāna sūtras. Imposing it on early Buddhist texts-as if they carried the essence of upāya without using the exact term-implies that the difference between explicit and implicit references is of no significance. However, the term upāya in Mahāyāna denotes a new awareness that is actually absent in pre-Mahāyāna Buddhism.

The Pāli for skillful means, upāya kusala, occurs only rarely and in the Pãli canon, and only one example in the Sutta Pițaka refers to the teachings of the Buddha. ${ }^{5}$ One verse in the Sutta Nipāta praises the one who helps many people to cross over. Here skillful means are said to be like an oar and a rudder in rough water. ${ }^{6}$ The 
metaphor is clear: the boatman helps others to cross over by using the oar and rudder as the Buddha helps others with his.skillful teaching. There is nothing here to suggest, as the Mahāyāna text would, that the Buddha used skillful means as a deception and that he tricked his followers in the right direction. In the Digha Nikāya there is a list of three skills including upāyakusala, ${ }^{7}$ which refers to a similar list from the Anguttara Nikāya. ${ }^{8}$ In both cases the text deals with normal skills of normal monks who come and go (or progress and regress), ${ }^{9}$ but no reference is made to the teaching of the Buddha.

Although scholars are generally aware that upāya does not occur often in preMahāyāna sources, the significance of this fact is rarely discussed. Often the Pāli raft simile in the Majjhima Nikāya is referred to as an example of skillful means. But a quick examination of the Pāli simile reveals that it expounds only a narrow view of skillful means that significantly differs from the Mahāyāna view. The story is as follows: a man builds a raft to cross over from the dangerous bank of a river to the safe one. Once he is across and about to continue his journey, he considers whether he should carry the raft with him. The Buddha concludes that although the raft served the man well for crossing over, the right thing to do is to leave it on the river's bank or to set it adrift in the water. The moral concludes: "So it is shown by me, Bhikkhus, that the Dhamma is like a raft, being for crossing over not for holding onto." 10

The conclusion is fairly clear. When one sees that the dhamma is like a raft there is no reason for clinging to it. The ridiculous image of a man carrying a raft on dry land makes little room for misunderstanding. The simile indeed says that the dhamma is of a pragmatic nature, and that one should be careful not to cling to it. It stresses the fact that the teaching is a means to an end, and is not the end itself. When the end is reached, the teaching can be left aside. But this is not to say that the dhamma was delivered with concealed intentions that contradicted its literal meaning. In the Lotus Sütra, as I show below, this controversial idea will become explicit and intensified. It would reach a point where the teachings are taken not only as skillful means, but as nothing but skillful means.

The distinction between implicit and explicit upāya has been noted by Damien Keown in his article "Paternalism in the Lotus Sütra." Keown suggests a four-stage evolutionary pattern of upāya. He explores some of the differences between the first stage, represented by the Pâli canon, and a second stage represented by the Lotus Sütra. ${ }^{11}$ Keown mentions that the Buddha adapted his audience's terminology in order to deliver his message: "What we are seeing here is the practice of skillful means before anyone had invented a special name for it."12 Regarding the second phase he writes:

The second phase in development of the concept is found in the Lotus Sütra, which crystallizes and makes explicit the notion of skillful means understood as a methodology for the transmission of the Dharma. ${ }^{13}$

Keown adds that the Lotus Sütra's significance lies in its claim that all teachings are provisional and ultimately to be dismantled. He then continues to describe the other 
phases: the third (in the Vimalakirtinirdeśa Sütra), in which skillful means becomes explicitly a part of the bodhisattva's development, and the forth, in which controversial actions performed by advanced bodhisattvas are explained as skillful means and are granted entry into normative ethics. ${ }^{14}$

The distinction between phases one and two is significant because it exposes the very point where the Mahāyāna shifted away from the preceding Buddhist system(s). In the context of the first phase, the term skillful means can only be used in a loose pedagogical sense: the Buddha used clever methods to deliver his message in the most appropriate way. The methods should not be clung to when the goal is reached. This is what John Hick called the "narrow sense of upayya":

In its narrower meaning it presupposes that a teacher knows some truth which is to be communicated to others so that they may come to see it for themselves; and the skilful means are the devices which the teacher uses to do this. Thus in the Pâli scriptures the Buddha is constantly using similes and parables and often asking skilfully leading questions. ${ }^{15}$

The implication of this is that teachings are not Truth and therefore that there is no reason to be attached to them. Although the term skillful means is not used in the raft simile, it roughly represents its spirit: the teachings are to be held as far as they work. But again, this is quite different from the explicit use of the concept in Mahāyāna.

In the second phase, upāya becomes a distinct and self-conscious hermeneutic tool. It clearly says that previous teachings of the Buddha were nothing but skillful means and therefore can be replaced by new teachings or even be abandoned altogether. Hick continues to explain the concept of skillful means in this manner, but without rendering a distinction between Mahāyāna and pre-Mahāyāna thought. He calls it the "comprehensive sense" of upāya:

In its more comprehensive sense, however, the concept expresses a profound insight, excitingly illuminating or deeply disturbing according to one's presuppositions, into the nature of Buddhism, and perhaps also into the nature of religion generally. ${ }^{16}$

It is profound and deeply disturbing because it suggests that the teaching of the Buddha is provisional-a mere means to an end. In this case, strictly speaking, skillful means is an abbreviation of "understanding that teachings are nothing but skillful means." Since the Buddha's teachings were only methods that were developed for the specific conditions of unenlightened beings, they can be replaced with new and better teachings when the conditions change, or, better, they can be abandoned altogether. But the message of the Lotus Sütra is even more provocative than this. It suggests that the Buddha actually played tricks and deliberately deceived his followers in order to help them achieve goals that were actually concealed from them at the time. Not only his words but also his actions and his biography were only means to an end. The Lotus Sütra treats them actually as a form of educational fiction. This sense of upãya is part of the message of the Lotus Sütra but cannot be found in early Buddhist texts. 


\section{The Opening Section}

The second chapter of the Lotus Sütra introduces the concept of "skillful means." The Buddha opens by saying that his wisdom is beyond comprehension for pratyekabuddhas and śrāvakas. This is, of course, a highly provocative statement, since they are thought to be-at least by non-Mahãyāna Buddhists—those who achieved the final goal and attained liberation. Naturally, it raises a question: how come those beings, who presumably had perfect wisdom, are now incapable of understanding? The Buddha's answer is that he had taught the path of pratyekabuddhas and śrāvakas only as skillful means to help beings escape suffering. In fact, he adds, it is not the final goal. The immediate implication of this statement is that they actually did not achieve what they thought to have achieved. The perplexity is only growing: what are the relations between the old teachings and this new statement? Did the Buddha deliberately lie to his disciples? Indeed, we read that arhats have all fallen into the net of doubt. ${ }^{17}$

In the opening of the second chapter the Buddha says that his wisdom is so profound that it cannot be penetrated by his followers. Surprisingly, the reason for this is explained as follows:

Shariputra, ever since 1 attained Buddhahood I have through various causes and various similes widely expounded my teaching and have used countless expedient means to guide living beings and cause them to renounce their attachments. Why is this? Because the Thus Come One is fully possessed of both expedient means and the paramita of wisdom. ${ }^{18}$

The Buddha, endowed with perfect wisdom and compassion, utilizes various devices to help other beings. The fact that it is hard to understand his wisdom is based on two premises: (1) his wisdom is perfect and therefore hard to grasp, and (2) his motivation also is perfect and hard to understand. In other words, one can only see the limited expression of the perfect motivation of the Buddha. Hurvitz comments that the passage from which this quote is taken is different in the Sanskrit Version and in Kumārajīva's version. ${ }^{19}$ Nevertheless, the basic idea is expressed by the Sanskrit as well:

The mystery (samdhābhāsya) of the Tathāgatas \&c., is difficult to understand, Śāriputra, because when they explain the laws (or phenomena, things) that have their causes in themselves they do so by means of skiffulness, by display of knowledge, by arguments, reasons, fundamental ideas, interpretation, and suggestions. By a variety of skilfulness they are able to release creatures that are attached to one point or another. The Tathāgatas \&c., Śäriputra, have acquired the highest perfection in skilfulness and the display of knowledge. ${ }^{20}$

Reading skillful means as pedagogical ability shrinks the great teacher to the size of a mundane skilled tutor-a notion that is beyond absurdity for the Lotus Sütra. His way of teaching is not dependent on skillful means alone but also on the perfection of wisdom. ${ }^{21}$ This is the first feature we meet in regard to the Lotus Sütra's notion of 
skillful means--it is skillful because the Buddha's perfections do not allow him to act in any other way.

Let us return to the original problem of chapter 2 of the Lotus Sütra. The concept of skillful means appears in the context of a controversy: did the Buddha teach three types of vehicles to liberation or did he teach that there is (and always has been) only one? The sūtra leaves no room for speculation: the true teaching of the Buddha is aimed only at Buddhahood. ${ }^{22}$ The goal of Buddhahood is superior to the goals of pratyekabuddhas and śrāvakas; these two were taught for the benefit of beings with strong attachments and little wisdom. ${ }^{23}$ These paths were, hence, only means to help beings enter the one and only path to Buddhahood, which is called also ekayāna (the only vehicle), mahāyāna (the great vehicle), or buddhayāna (the vehicle that leads to being a Buddha). On top of these teachings, all similes, parables, sūtras, logical expositions, the teaching of nirvāna, the end of suffering, and even the life and death of the Buddha were-according to the Lotus Sütra-skillful means used by the Buddha for the sake of attracting those beings to the buddhayana. Since skillful means is the product of the enormous wisdom and extreme compassion of the Buddha, it cannot be morally wrong in any sense. Providing this premise at the beginning of the chapter helps to solve a problem that will arise sooner or later: it looks as if the Buddha had deliberately deceived his disciples by not revealing the whole picture.

This exposition, of course, only strengthens the division seen earlier between the audience and the Buddha. As Paul Williams states, the Buddha in this context is infinitely superior to anyone else; his understanding of the dharma "can only be understood and shared between Buddhas." ${ }^{24}$ Even Sāriputra, who is considered to be an arhat by the early tradition, cannot understand the dharma realized by the Buddha since-and the sütra definitely uses any opportunity for telling us this_-"only those who are Buddhas can understand it." 25

It is no surprise that a thread of confusion and bewilderment, expressed by the audience, accompanies this chapter. If Buddhas alone know the true meaning of the teaching, what is the status of the very text that makes the claim? Is this another expression of skillful means that should not be taken literally? If so, what is the true meaning behind it? Assuming that we are yet not Buddhas, can we actually understand the sūtra? In other words, it is a version of the paradox "no one can understand this sentence." 26

A way to solve the problem is by stressing the idea that the religious practice should involve a great deal of faith and belief. Since one cannot fully understand the ultimate meaning of the teachings, one should accept that they are coming from a source of infinite wisdom and compassion beyond one's understanding. Indeed, bodhisattvas can understand the incomprehensible dharma because they are "firm in the power of faith." 27 Sāriputra is told that he and others "should with single mind[s] believe and accept the words of the Buddha." 28 Moreover, "it is because they have faith in the Buddha's words that they can comply with this sūtra not because of any wisdom of their own." 29 This point should draw our attention to an important issue. It shows that the Lotus Sütra is aware of its being a text-it does not 
pretend to serve as a transparent medium that reflects truth as it is. This awareness is inseparable from the way the Lotus Sütra understands upāya: the teachings of the Buddha were never completely transparent and should never have been taken literally. ${ }^{30}$

\section{Skillful Means in the Similes}

The Lotus Sütra makes use of similes and parables to further clarify upāya, "for through similes and parables those who are wise obtain understanding. "31 Some relevant issues arise from the similes. There is a tremendous gap between what the Buddha knows and what his followers know. This gap allows the Buddha to use all kinds of trickery and deception for their benefit. Surprisingly, we, the readers of the sūtra, share the same point of view with the Buddha. The historical deception is exposed in front of our privileged eyes. In addition, it is clear that the eyes of the followers were blinded to the true situation by lack of knowledge. This is one major justification for using the deceptive "skillful means." All similes end with a revelation of truth and come together with a full justification of the trickery. This reflects the status of the Lotus Sütra itself as the exposer of high truth.

\section{The Burning House}

The most famous of all the parables is probably the story of the burning house. The following is a brief summary of the story. The house of a rich man is set on fire. His children are playing inside the house, so focused on their games that they ignore the danger. The man thinks about different ways for saving his children like grabbing them all and taking them by force, or directly explaining to them the nature of the danger. However, these solutions are doomed to fail because of physical limitations and the children's blindness toward the danger. Then, the man thinks: "I must now invent some expedient means that will make it possible for the children to escape the harm." 32 Being aware of his children's passions, he tells them of the wonderful toys that are waiting for them outside the house-a goat cart, a deer cart, and an ox cart. When the children are out and safe he gives each of them a fantastically decorated carriage pulled by white oxen-even better then the promised toys!

The toy vehicles stand for the lesser vehicles-pratyekabuddhayana and śrāvakayāna-the great oxen carriage represents the buddhayāna. We are left with the small ox cart, which should represent a lesser vehicle, but because of the ox it implies similarity to the buddhayāna oxen carriage. In fact, there are no three vehicles, pratyekabuddhayāna, śrāvakayāna, and buddhayāna, but only one, buddhayāna. The buddhayāna, which was thought previously to be one of three vehicles, is actually, according to the Lotus Sütra, the only one that actually exists. ${ }^{33}$ On top of all this, in the analysis of the story Saariputra admits that the carriage was not so important (in the story), since the skillful means of the rich man would have worked even without any compensation - after all, he saved their lives! What is important in the eyes of the sütra is the benevolent motivation of the father - the rest is only means. 
This story presents a basic idea regarding skillful means. It is done for the sake of beings that are trapped in a dangerous situation without knowing that they are in danger. It involves tempting and attracting them to a safe place, in which a better gain is offered. It presents the aspects of lying, motivation, and results. Keown makes a helpful distinction between the intention to lie and the motivation. The motivation is surely justified, while there is not any doubt, according to this story, that the Buddha/father intended to lie. ${ }^{34}$ The sūtra claims that when the motivation and results are good, and the benefit of someone else is under consideration, what seems to be lying is actually not lying. In the words of the sütra the father "did not commit a falsehood." 35 This suggests, hence, that the former teachings of the Buddha, the teachings of the three paths to liberation, carried the attributes of lying for bringing better results. However, due to benevolent motivation this cannot be condemned.

\section{The Phantom City}

A similar idea is expressed in the story of the phantom city. Here, again, there is a lie, or a trick, which turns out to be to the benefit of those who are deceived. In a nutshell, a magician guide creates a resting place in the middle of the wilderness so that his band can relax before continuing on to their goal, to the real city. ${ }^{36}$ From the various translations of the title Burton's "phantom city" is the most adequate because it exemplifies the fact that the city is real and not real at the same time. It is real because the group can actually rest there and escape the dreadful road. It is not real because the leader creates it and makes it disappear by his will, and because it is contrasted with another city, the goal of the trip, which is not created by the leader.

With this story we get more information about the status of skillful means with regard to truth. What the Buddha had previously taught is both true and not true. Teaching nirvāna to pratyekabuddhas and śrāvakas was not a simple lie or a vulgar trick; it was like the creation of a phantom camp in the middle of the way to the real goal. "The other two nirvanas are preached to provide a resting place." 37 The need for this story arises from the fact that the hearer of the sūtra could have felt that the two paths were nothing else but pure trickery. ${ }^{38}$ The story, hence, explains the relations between the new teaching and the old teaching.

A second aspect of this story touches the issue of gain and loss. When the journey is difficult, the members of the wandering group complain that they would like to turn around and go back. ${ }^{39}$ If they do so they will lose the chance to enter the treasure city, the final goal of their journey. But entering the phantom city has them feeling "overjoyed in mind" and at "complete ease and tranquillity." 40 It seems as if they will stay there forever unless the leader wipes away the phantom experience. By deserting the resting place the people achieve a greater gain; however, only the leader, who alone can compare the phantom city to the treasure city, knows this. He causes the phantom city to disappear, an act that must be understood as an allegory for wiping away the teachings of various paths. This is exactly what the Lotus Sütra does. 


\section{The Lost Son}

The third story to be analyzed here is that of the son who did not recognize his father. A young man leaves his father and wanders abroad for years. Later he accidentally comes to the city where his father lives; in the meantime the father has become very wealthy. The father recognizes the son, but the son does not recognize the father. The father realizes the difficult situation and does not reveal his relationship to him. Instead he employs the son, slowly building up his confidence until he can treat him as an adopted son and give him responsibilities for the whole estate. At last the father, who is near the end of his life, calls together many witnesses and reveals the true, original relationship.

According to the sūtra, the father acts skillfully three times. First, he recognizes the problem and avoids using direct action; second, he gives his son smaller jobs, but pays him double; third, he makes an effort to be close to him and gain his trust, an act that helps to build the son's confidence. As in the two previous stories there is a gap between what the chief character knows and what the others know, and trickery and disguise take place to benefit someone. ${ }^{41}$

We-the readers or hearers of the story - share the point of view held by the allknowing character. We know what the son does not know. If only he had known the true situation, there would not have been a need for the father to engage in all of this difficult deception! This feature, however, is unique to this story and not present in the others. The low position occupied by the son at the beginning could, hypothetically, have been exchanged for a higher position at any given time, including at the very beginning. The only thing that separated him from this high position was his own ignorance. This cannot mean anything else but that we are actually the sons of the Buddha, although this fact has been hidden from us for a long time and for good reasons.

Another interesting feature of upāya is revealed in the final act. Toward the end of his life, the father reveals his use of skillful means and proclaims the true story. This again is a self-reference to the teaching of skillful means in the Lotus Sütra. The final act is not only about the status of a previous teaching but also about the status of this very story in this very sūtra. The father shares his point of view with the son in the same way that the Lotus Sütra shares the Buddha's point of view with us.

To sum up the similes, there are five common features to the stories about skillful means. First, there is a gap between what one character knows and what the others know. This is the gap between the truth, known by the Buddha, and the relative and often mistaken view of the others. Second, we, the readers/hearers of the sūtra, share the same point of view with the all-knowing character. Third, the other characters suffer from some sort of blindness to the situation, ignorance of some sort, fear, or a limited view. Due to this, the all-knowing character cannot reveal the truth as a whole and is forced to use skillful means. Fourth, his motivation is compassion, and he acts with wisdom, understanding well the situation and the limits of the others. Finally, by the end of the story, the truth is revealed together with a full justification for the trickery involved. 
The similes reveal the importance of the interplay of literal expressions and their meaning. On one level the sūtra tells stories in which there is a clear gap between what is said and what is meant. This shall be referred to as the "text level." On this level the distinctions are clear-the all-knowing character helps the underprivileged followers, who are saved by not knowing the truth. On a higher meta-textual level, the reader (or the hearer) shares a point of view with the producer of true meaningthat is, the Buddha. Hearers are thus encouraged to feel privileged in their critical position, because they can now see what has been previously disguised. For the readers this experience is one of revelation. It assists in the setting aside of wrong ideas and concepts, and the achieving of a new orientation toward the real goal. At this level the readers of the sūtra seem to be saved by knowing the truth. But this truth is rather elusive. Although it precisely exposes what is not true, that is, the previous conceptions of three vehicles, et cetera, it offers hardly any positive content to contemplate. The lucid demonstration of skillful means does not counteract the statement that only Buddhas share the point of view of Buddhas.

There are two possible solutions to this apparent difficulty; both are found in the sūtra and both are Mahāyāna novelties. First, because the Buddha is infinitely higher than the follower, and because his point of view is so privileged, the follower progresses and establishes himself on the path by growing in faith. Second, as the meta-textual level of the simile suggests, the follower can actually share the same point of view as the Buddha because he is, in a sense, already on the path to Buddhahood; he simply is not aware of this fact. Like the returning son, the ignorant follower possesses all the necessary attributes to perform well, without actually having an awareness of his true nature. When this problem is resolved, everything else is taken care of. Using the idea of skillful means, the Lotus Sütra promotes these two doctrinal ideas and at the same time digests, or, as one scholar has put it, "cannibalizes" the early doctrine. ${ }^{42}$

\section{Skillful Means and the "Historical" Buddha}

One section of the Lotus Sütra demonstrates how the life of the historical Buddha was in fact a manifestation of skillful means. ${ }^{43}$ We learn that the Buddha actually attained Buddhahood in a relatively short time. His life span "is an immeasurable number of asamkhya kalpas," and during this time he has "constantly abided here without ever entering extinction." 44 This fits, of course, very well with the Mahāyãnic view that the Buddha is still present and can continue to provide teachings even after his apparent death. ${ }^{45}$

In the Lotus Sütra, there are two reasons why a human life-course manifests itself, and both involve skillful means. First, the Buddha, by manifesting a normal human life, tells his followers that he is going to die. Knowing this, they understand that "it is a rare thing to live at a time when one of the Buddhas appears in the world," 46 and, hence, they make the extra effort and achieve progress on the path. ${ }^{47}$ What we know about the life of the Buddha Śăkyamuni comes from a narrative that is very much like a staged play in which the Buddha is an actor. In this way life 
becomes fictional presentation, a text, a performance. It represents something other than itself. Second, the Buddha tells his life story for those who are "meager in virtue and heavy with defilement." 48 Because they "delight in a little Law" and are in need of inspiration, he describes how he left his household and attained Buddhahood. ${ }^{49}$ The following passage leaves no doubt concerning the interpretation of the narrative: "the scriptures expounded by the Thus Come One are all for the purpose of saving and emancipating living beings." 50 I have no access to the original Chinese but it seems that Hurvitz, Watson, Kubo, and Yuyama agree that this sentence refers to a previous Buddhist canonical text. ${ }^{51}$ Whether "scriptures" here denotes a written text or an oral one is an open question; however, there is little doubt that it refers to an actual body of words. The Sanskrit uses the term dharmaparyāya, which means "a way of preaching the Dharma" and directly refers to the form of early teachings as presented in the early sūtras/suttas. ${ }^{52}$ In this context, dharmaparyāya is treated precisely as a fictional story for the purposes of education. The history of the Buddha is treated as story, a fiction, something that does not represent actual fact.

In the Upãyakauśalya Sūtra this idea is expanded to the maximum. In this sūtra skillful means explains (or at least tries to) every tiny bit of information about the life of Śăkyamuni. Why did the bodhisattva enter into a trance in the shade of a Jambu Tree? Why did he leave home at midnight? Why did he practice austerities for six years? Why did he receive food before his awakening? Why did he not gain enlightenment before Mārā arrived? Without going into detail, all these questions (and many more) have a common answer: all this was done as part of his teaching, in order to help and encourage other beings to take the path. ${ }^{53}$

The life of the Buddha as a whole becomes a lesson in "skillful means." History becomes story. Furthermore, the old biography is replaced by a new biography in which the Buddha has practiced the bodhisattva path and has attained Buddhahood many eons before. Every event in his life, including the mere fact that he had "a life," is said to be a staged performance for the benefit of his followers.

\section{Conclusion}

Upãya in the Lotus Sütra serves as an explanatory and apologetic instrument for justifying a new approach to Buddhist teachings. It reads previous teachings as texts, not as facts, and offers new textual interpretations. The literal understanding of the teachings is directly criticized-they are presented as lies and tricks aimed at the least capable of followers. They should really be understood, says the sūtra, as expression of skillful means; they have hidden and hard-to-grasp meanings. The idea that the Buddha may say one thing but intend another is radically new. It exposes a high degree of awareness to the hermeneutic possibilities regarding doctrine and biography. This maneuver is done in order to justify a new doctrine embodying a strong faith element. As such, it is a winning formula: it defends a new doctrine without totally condemning the previous one. It manages to digest the previous teachings into a bigger and improved system of thought. 
As seen in the story of the burning house, the teaching of the three vehicles, although a lie, is not seen as morally wrong. This duality features in the other stories as well. In this way the Lotus Sütra hugs the old teachings to death, offering a new reading of what is already known, and possibly canonical, scriptural truths. "Cannibalizing" texts, as Harrison calls it, does not necessarily demand that a written format be present in front of the "cannibal."54 However, it does demand the existence of a fixed text of some sort-oral or written. After a text becomes fixed, new tactics may be employed to attack it. One tactic might be to ridicule the mere creation, the raison d'être, of the old text; another might be to defend the superior position of the attacking text. Upāya serves both. It tells us that old teachings were designed for those who lacked wisdom, but at the same time it offers an opportunity to see the Lotus Sütra as a teaching of higher order. This kind of teaching, we are told, should be preached and preserved and should be approached with great faith.

Skillful means here is a hermeneutic device that helps to justify the process of reinterpretation of the historical narrative of the life of the Buddha and his teachings. The division between history, story, life-story, and teaching does not seem to be of great importance for the sūtra. As shown above, the actual life of the Buddha becomes another type of skillful means, exactly like other stories, similes, and parables. This can only happen after the biography and the teaching have achieved a certain canonical status. Of course, no biography of the Buddha that we know of can be considered as simply a historical or factual account. It is clear, for example, that the story in the Ariyapariyesanā Sutta has its own special purposes and therefore is better seen as hagiography than history. ${ }^{55}$ Nevertheless, the Palli text does not acknowledge the double meaning that characterizes the concept of upāya. In the Pāli text, facts are at least presented as facts. This attitude is definitely absent in the Lotus Sūtra and in the Upāyakauśalya Sütra. There, although one story is told, another is true. If we call the old story "text," then upāya serves as a commentarial reaction that exposes its true and counter-literal meaning.

In the eyes of the Lotus Sütra there is a clear distinction between the apparent "objects" of reality, either the teachings or the actual life of the Buddha, and their true meaning. Upãya explains how previous knowledge about the teachings, the goals, the paths, and the biography of the teacher is both unreal and real. It is a phantom. In this way, the new Mahāyāna ideology manages to reject the old, to offer a new religious orientation, and at the same time avoid complete heresy. After all, it claims, the tricks, deceptions, and lies were all skillful means: they were all designed by perfect wisdom and for a perfectly good cause.

Skillful means is therefore not a mere pedagogical device of matching the right simile to the right person. It is also not exactly the idea that the teachings should be abandoned after a person reaches a goal. It is rather a sophisticated explanatory tool that enables a new religious movement to claim that what has been widely accepted as true is actually not true, and that truth is, and has always been, something else. It is a pointer to a new gap that has been recognized between textual factsbiographical facts and doctrinal facts - and their other, hidden, meaning. 
1 - See, e.g., Williams 1989, p. 143; Pye 2003, p. 1; and Gombrich 1996, p. 17.

2 - The quote is from Pye 1978, p. 2.

3 - Schroeder 2002, Schroeder 2004, and Hick 2004.

4 - Pye (2003, p. 119) writes: "The way in which the term [upāya] comes to prominence in the Mahāyāna reflects characteristics of early Buddhism which are themselves generally reckoned to be of central importance." Gombrich (1996, p. 17) writes: "It is true that the term translated 'skill in means' upāya-kauśalya, is post-canonical, but the exercise of the skill to which it refers, the ability to adapt one's message to the audience, is of enormous importance in the Pāli canon." Schroeder (2000, p. 562) writes: "An obvious example of "skillful means" in the pre-Mahāyāna Pāli canon is found in the Majjhima Nikāya. In a famous section of this text, the Buddha describes his teachings as "rafts" that are used to ferry sentient beings across the turbulent waters of samsāra, and says that one should refrain from seeing his teachings as more than helpful devices." Hick (2004, par. 4) writes: "It [the concept of upāya] first appears in this broader sense in the Buddha's parable of the raft in the Majjhima Nikāya."

5 - Although there is little hard evidence that the complete canon that has arrived to us existed when Mahāyāna began, it is widely accepted that that at least portions of it go back as far as the third century B.C.E. (Gethin 1998, p. 42; Gombrich 1996, pp. 8-10). These portions are considered earlier than the earliest strata of the Saddharmapundarīka Sütra and other Mahāyāna texts (Pye 2003, p. 178; Williams 1989 , p. 142). These portions do not contain anything remotely close to the early Mahāyāna idea of skillful means. There may be one hypothetical objection to using the Pâli canon as an example for the nonexistence of upāya in pre-Mahāyana thought: the Theravāda tradition might have known all about it but erased any trace of the concept from the Pāli. However, it is not only the term that is missing but also the awareness of the gap between literal expressions and their hidden meaning.

6 - Sn 56: "yathā pi nāvaṃ dậham āruhitvā, piyen' arittena samañgibhūto so tāraye tattha bahū pi añ̃̃e, tatrūpayañ̃̃ū kusalo mutīmā" (Andersen and Smith 1913, p. 56).

7 - D iii 220.

8 - A iii 431 (Morris 1887, p. 431).

9 - See Pye 2003, p. 118, for a discussion and comparison of two translations of the paragraph. Either way the Anguttara and Digha Nikãyas do not use upãya in the same technical way that the Lotus Sütra does.

10 - M i 135: "evam 'eva kho, bhikkhave, kullūpamo mayā dhammo desito nittharanatthāya, no gahaṇatthāya" (Trenckner 1925, p. 135). 
11 - Keown 1998.

12 - lbid., p. 202.

13 - Ibid.

14 - Ibid., p. 203.

15 - Hick 2004, pars. 2-3.

16 - Ibid.

17 - Watson 1993, pp. 26-28. In this section ! have used two English translations of the Lotus Sütra, one by Watson (1993) and one by Kubo and Yuyama (1993). Page numbers refer to the translation made by Watson unless otherwise stated.

18 - Watson 1993, p. 24.

19 - Hurvitz 1976, p. 349.

20 - Kern 1884/1963, pp. 30-31. For comparison see also Hurvitz 1976, p. 349.

21 - Borrowing a beautiful example from the prajñā-pāramitā literature: "as a bird needs two wings to maintain itself in the air, so a bodhisattva needs both wisdom and skill in means to hold himself up in emptiness" (Conze 1968, p. 44).

22 - "The thus come one has only a single Buddha vehicle" (Watson 1993, p. 31).

23 - Watson 1993, p. 34.

24 - Williams 1989, p. 143.

25 - Watson 1993, p. 31.

26 - The difference is that instead of "no one" we have "only buddhas" (see also note 30 below).

27 - Watson 1993, p. 25.

28 - lbid., p. 33.

29 - Ibid., p. 73.

30 - Another way of solving the paradox is to acknowledge that being a Buddha is actually not as difficult and rare an achievement as it seems. Thus, the paradox "only Buddhas can understand this sentence" is solved when one acknowledges that in fact everyone is already a Buddha. There is some evidence that this position is found in the Lotus Sütra (Kubo 2008).

31 - Watson 1993, p. 56.

32 - lbid., p. 57.

33 - Williams 2000, p. 169.

34 - Keown 1998, p. 194.

35 - Watson 1993, p. 58. 
36 - lbid., pp. 135-136.

37 - Ibid., p. 142.

38 - The term upãya basically means a way to achieve a goal, but it may carry a slight negative meaning as well when it is rendered as 'a trick' or 'a way to win the enemy' (see definitions in Monier-Williams 1899/1999 and Rhys Davids 1921-1925). The Chinese equivalent (fang-pien), too, as Pye indicates, does not necessarily carry a positive ethical meaning when used outside the Buddhist context (Pye 2003, p. 12).

39 - Watson 1993, p. 136.

40 - Ibid.

41 - It is also common to the two stories about the hidden jewel, which are not discussed here. These stories, found in the eighth and fourteenth chapters of Kumārajīva's version, do not give new significant information about skillful means on top of what is provided by the other stories. Basically, the gap between knowing and not knowing is there, as well as the fact that if the person had only known he had a jewel, his life would be different.

42 - Harrison 2004, p. 20 n. 53.

43 - Watson 1993, p. 227.

44 - Ibid. (both quotes).

45 - Williams 2000, p. 108 . As for the sūtra itself, there is no debate about the date or place of its composition. The frame story suggests that the Buddha is speaking on this very earth during his lifetime (and not, for example, in another heavenly place). We know that Chinese tradition did not see any difficulty in the Lotus Sütra's being the last teaching of the historical Buddha before his apparent death. Nevertheless, scholars agree that it was composed sometimes between the first century B.C.E. and the first century C.E., several hundred years after the death of the Buddha (see Williams 2000, p. 169; for a detailed account based on the work of Japanese scholars see Pye 2003, p. 178).

46 - Watson 1993, p. 227.

47 - Even the Buddha's (apparent) death aims to achieve the same purpose, as shown by the simile of the physician who faked his death in order to save his poisoned and out-of-their-mind sons.

48 - Watson 1993, p. 226.

49 - Ibid.

50 - Ibid.

51 - Hurvitz (1976, p. 239) translates the Chinese as "the scriptural canon preached by the Thus Come One is all for the purpose of conveying living beings to deliverance." Kubo and Yuyama (1993, p. 237) translate this as "The sutras which the Tathāgata has expounded are all to save the sentient beings." 
52 - The equivalent Pāli (pariyāya) is specifically used in the Abhidhamma to denote the mode of teaching in the suttas, the illustrated and figurative presentations that are not abstract and not technical in character (Pâli English Dictionary, pariyāya no. 5, p. 433).

53 - Tatz 1994, pp. 60-68.

54 - Harrison 2004, p. 20 n. 53.

55 - M i 164 (Trenckner 1925, p. 164).

\section{References}

Andersen, D., and H. Smith, eds. 1913. Sutta-nipāta. London: Luzac and Co. for Pāli Text Society.

Conze, Edward, trans. 1968. Selected Sayings from the Perfection of Wisdom. 2nd ed. London: The Buddhist Society.

Gethin, Rupert. 1998. The Foundations of Buddhism. Oxford: Oxford University Press.

Gombrich, Richard. 1990. "How the Mahāyāna Began." In The Buddhist Forum 1, edited by Tadeusz Skorupski, pp. 21-30. London: School of Oriental and African Studies.

1996. How Buddhism Began. London: Athlone Press.

Harrison, Paul. 2003. "Medium and Messages-Reflection on the Production of Mahāyāna Sūtras." Eastern Buddhist, 35(1-2), pp. 115-151.

Hick, John. 2004. "Religion as 'Skilful Means."" http://www.johnhick.org.uk/ article9.shtml.

Hurvitz, Leon, trans. 1976. Scripture of the Lotus Blossom of the Fine Dharma. New York: Columbia University Press.

Keown, Damien. 1998. "Paternalism in the Lotus Sütra." Journal of Buddhist Ethics $5: 190-207$.

Kern, H., trans. 1884/1963. Saddharmapundarika or the Lotus of the True Law. Reprint, New York: Dover Publications.

Kubo, Tsugunari. 2008. "Bodhi and Anuttara-Samyak-Sambodhi in the Lotus Sutra." Paper presented at the XVth international Association of Buddhist Studies Conference, Atlanta, June 28.

Kubo, Tsugunari, and Akira Yuyama, trans. 1993. The Lotus Sutra: Translated from the Chinese of Kumārajiva. Berkeley: Bukkyō Dendō Kyōkai and Numata Center for Buddhist Translation and Research.

Monier-Williams, M. 1899/1999. A Sanskrit English Dictionary: Etymologically and Philologically Arranged with Special References. Delhi: Motilal Banarsidass. 
Morris, R. 1897. Añguttara-Nikāya, Vol. 3, London: Pāli Text Society. Reprint edition 1994.

Pye, Michael. 1978/2003. Skilful Means-A Concept in Mahayana Buddhism. London: Routledge.

Rhys Davids, T. W., and William Stede. 1921-1925. The Päli English Dictionary. Oxford: Pāli Text Society.

Schroeder, John W. 2002. "Nāgārjuna and the Doctrine of 'Skillful Means." Philosophy East and West 50 (4): 559-583.

- 2004. Skillful Means: The Heart of Buddhist Compassion. Delhi: Motilal Banarsidass.

Tatz, M., trans. 1994. The Skill in Means (Upãyakauśalya) Sūtra. Delhi: Motilal Banarsidass.

Trenckner V., ed. 1925. Majjhimanikāya. Vol. 1. London: Pāli Text Society.

Watson, Burton, trans. 1993. The Lotus Sutra. New York: Columbia University Press.

Williams, Paul. 1989. Mahāyāna Buddhism-The Doctrinal Foundations. London: Routledge.

2000. Buddhist Thought-A Complete Introduction to the Indian Tradition. London: Routledge. 
Copyright of Philosophy East \& West is the property of University of Hawaii Press and its content may not be copied or emailed to multiple sites or posted to a listserv without the copyright holder's express written permission. However, users may print, download, or email articles for individual use. 